\title{
Factors associated with risk, perception and knowledge of falls in elderly people
}

\author{
Fatores associados ao risco, à percepção e ao conhecimento de quedas em idosos \\ Factores asociados con riesgo, percepción y conocimiento de caídas en ancianos
}

\author{
Lidia Ferreira de Souza ${ }^{a}$ \\ Ruth Ester Assayag Batistab \\ Cássia Regina Vancini Camapanharo ${ }^{b}$ \\ Paula Cristina Pereira da Costa ${ }^{c}$ \\ Maria Carolina Barbosa Teixeira Lopes ${ }^{\mathrm{b}}$ \\ Meiry Fernanda Pinto Okunoc
}

\section{How to cite this article:}

Souza LF, Batista REA, Camapanharo CRV, Costa PCP, Lopes MCBT, Okuno MFP. Fatores associados ao risco, à percepção e ao conhecimento de quedas em idosos. Rev Gaúcha Enferm. 2022;43:e20200335. doi: https://doi.org/10.1590/19831447.2022.20200335
Universidade Federal de São Paulo (UNIFESP), Escola Paulista de Enfermagem, Programa de PósGraduação em Enfermagem. São Paulo, São Paulo, Brasil.

' Universidade Federal de São Paulo (UNIFESP), Escola Paulista de Enfermagem, Departamento de Enfermagem Clínica Cirúrgica. São Paulo, São Paulo, Brasil.

Universidade Federal de São Paulo (UNIFESP), Escola Paulista de Enfermagem, Departamento de Saúde Coletiva. São Paulo, São Paulo, Brasil.

\begin{abstract}
Objective: To verify the factors associated with risk, perception, and knowledge of falls; and pain among older adults.

Method: A cross-sectional study carried out in the Emergency Service of a teaching hospital in the city of São Paulo between September 2019 and March 2020. We selected 197 older adults aged 65 and over, who were not disoriented or confused, of both genders. The instruments Awareness Questionnaire on the Risk of Falls, Morse Fall Scale and Numerical Pain Scales were applied. Mann-Whitney and Kruskal-Wallis tests were used.

Results: Interviewees with a high risk of falls in older adults $(p=0.0041)$; those with a support network had a lower perception and knowledge about the risk of falls $(p=0.0025)$ and lower percentage of severe pain $(p=0.0033)$.

Conclusion: Factors associated with risk, perception and knowledge of falls and pain among older adults were age, family income, number of dependents, caregiver, support network, hypertension, impaired walking, antihypertensive medication, lipid-lowering medication, level of education, comorbidities and religion.
\end{abstract}

Keywords: Aged. Accidental falls. Emergency service, hospital. Hospitals.

\section{RESUMO}

Objetivo: Verificar os fatores associados ao risco, percepção e conhecimento de quedas; e dor em idosos.

Método: Estudo transversal realizado no Serviço de Emergência de um hospital de ensino da cidade de São Paulo, entre setembro de 2019 e março de 2020, selecionados 197 idosos com 65 anos ou mais, que não estavam desorientados e confusos, de ambos os sexos. Aplicou-se: Falls Risk Awareness Questionnaire, Escalas de Queda de Morse e Numérica de Dor. Utilizaram-se testes Mann-Whitney e Kruskal-Wallis,

Resultados: Entrevistados com risco alto de quedas apresentaram maior idade $(p=0,0041)$, aqueles com rede de apoio tiveram menor percepção e conhecimento do risco de queda $(p=0,0025)$ e apresentaram menor percentual de dor intensa $(p=0,0033)$.

Conclusão: Fatores associados ao risco, percepção e conhecimento de quedas e dor em idosos foram idade, renda familiar, número de dependentes da renda, cuidador, rede de apoio, hipertensão, défice de deambulação, anti-hipertensivos, hipolipemiantes, escolaridade, comorbidades e religião.

Palavras-chave: Idoso. Acidentes por quedas. Serviço hospitalar de emergência. Hospitais.

\section{RESUMEN}

Objetivo: Verificar los factores associados al riesgo, percepción y conocimiento de caídas; y dolor em ancianos em un Servicio de Urgencias.

Método: Estudio transversal realizado em el Servicio de Urgencias de um hospital universitário de la ciudad de São Paulo, entre septiembre de 2019 y marzo de 2020, se seleccionó a ancianos mayores de 65 años, que no se encontraban desorientados ni confundidos. Se incluyeron 197 ancianos de ambos sexos. Se aplicaron el Falls Risk Awareness Questionnaire, la Escala de Caídas Morse y la escala numérica de dolor. Se utilizaron las pruebas de Mann-Whitney y Kruskal-Wallis.

Resultados: Los entrevistados com alto riesgo de caídas eran mayores ( $p=0,0041)$, los que tenían uma red de apoyo tenían menor percepción y conocimiento del riesgo de caídas $(p=0,0025)$ y tenían menor percentaje de dolor severo $(p=0,0033)$.

Conclusión: Los factores asociados al riesgo, percepción y conocimiento de caídas y dolor en los ancianos fueron edad, ingresos familiares, número de dependientes, cuidador, red de apoyo, hipertensión, discapacidad para caminar, antihipertensivos, hipolipemiantes, educación, comorbilidades y religión.

Palabras clave: Anciano. Accidentes por caídas. Servicio de urgencia en hospital. Hospitales. 


\section{口INTRODUCTION}

The evaluation of the health condition of older adults is a major challenge for health professionals $s^{(1)}$. The aging process is often followed by increased morbidity, changes in gait, increased frailty, dependence, and pain associated with decreased functionality ${ }^{(1)}$

Thus, this population is at increased risk of falls, and one third of all self-employed older adults over 65 years of age can expect to have a fall in the course of one year ${ }^{(2)}$ Dependent and frail older adults have a higher prevalence of risk factors and, for this reason, may have more falls. Therefore, healthcare professionals must provide an adequate health assessment to predict this event ${ }^{(3)}$

According to Kellogg International Work Group on the Prevention of Falls by the Elderly, a fall can be defined as a sudden, unintentional change in position, causing an individual to land at a lower level compared to their initial position, such as on furniture or on the floor ${ }^{(4)}$

One of the main causes of death and the most frequent reason for visits to the Emergency Service among older adults is falls, which represent almost $50 \%$ of all trauma care ${ }^{(5-6)}$ As people age, they are more likely to fall. Although most fall-related injuries are less severe, they can cause significant pain and discomfort, affect older adults' confidence, and lead to loss of independence. Some falls can cause serious health problems in the long term ${ }^{(6)}$

Falls in-hospital are frequent adverse events that increase morbidity and mortality, the length of hospital stays, and healthcare costs. These events can also affect the quality of life of hospitalized patients. In 2014, falls were the third most reported adverse event in hospitals in Brazil. The main victims of falls in-hospitals are older adults, who are affected by the changes associated with senescence and senility, the increase in chronic diseases, the consequent use of multiple medications and the presence of pain ${ }^{(7)}$

In fact, falls are a significant public health problem due to their consequences, such as increased risk of subsequent falls, hospital readmission, functional decline, mortality, fear of falling again and social isolation ${ }^{(8)}$ Having better perception and knowledge of the risks of this event can help older adults to implement preventive measures, reducing falls in the hospital environment ${ }^{(9)}$ Pain can impair posture, balance and gait, becoming a risk factor for falls in these environment ${ }^{(10)}$

This study occurs in this context and aims to verify the factors associated with risk, perception and knowledge of falls; and pain among older adults.

\section{METHOD}

Cross-sectional and analytical study, carried out in the Emergency Service (ES) of a teaching hospital linked to a federal university in the State of São Paulo, in the Southeast region of Brazil. Data was collected from September 2019 to March 2020.

The inclusion criteria in the study were older adults aged 65 years or over, as recommended by the Falls Risk Awareness Questionnaire (FRAQ-Brasil) ${ }^{(11)}$ Older adults who were disoriented and confused or had a record of dementia in their medical records were not included. All older adults included in the study remained until the end.

The sample size was calculated using stratified probability sampling proportional to the mean number of older adults aged 65 years and over hospitalized in the six months preceding the survey. The software used for sample calculation was Minitab. The calculation considered a confidence level $\geq 80 \%$ and alpha $5 \%$, based on the variables age, gender, level of education, marital status, length of hospital stays in days, family income and comorbidity. The sample calculation indicated the need for a minimum sample of 197 older adults to achieve the objectives proposed, and this was the number of participants included in the study. A structured questionnaire was used for data collection, with information on age, gender, education, marital status, occupation, length of hospital stays, family income, having or not having a caregiver, religion, morbidities and having or not having a support network in the community.

The level of perception and knowledge about falls among older adults was evaluated using the FRAQ-Brazil instrument in its different dimensions, with 25 closed questions and a total of 32 points. The questionnaire score ranges from zero to 32 points; the higher the score, the better the perception and knowledge about the risks of falls of that participant ${ }^{(11-12)}$

The risk of falls was evaluated using the Morse Fall Scale, which consists of six criteria: history of falling, secondary diagnosis, ambulatory aid, intravenous lock, gait and mental status. Each criterion evaluated receives a score ranging from zero to 30 points, totaling a risk score, in which zero to 24 points indicate low risk; 25 to 44 indicate medium risk; and scores $\geq 45$ indicate high risk ${ }^{(13-14)}$

Pain intensity was assessed using a numerical scale. Pain intensity was categorized as zero for no pain; 1 to 4 for mild pain; 5 to 7 for moderate pain and 8 to 10 for severe pain ${ }^{(15)}$.

The inpatient sector was asked for a daily list of patients aged 65 years or over admitted to the hospital's Emergency Department. Then, the researcher went to the unit and 
consulted the medical records, assessing the evolution of the patient's level of consciousness and mental state, according to the interprofessional team, to make sure they were able to understand and answer the questionnaires and instruments of the study. Then, the patients were contacted to confirm the fulfillment of the inclusion criteria.

All older adults aged 65 years or over who met the inclusion criteria were approached and invited to take part in the study. When they agreed, they were interviewed individually. The instruments were read by the researcher in a single meeting, with an average duration of 40 minutes.

Descriptive analysis was used for socio-demographic, clinical and economic characterization and for the variables having a caregiver, religion and support network in the community. For categorical variables, frequency and percentage were calculated. For continuous variables, median, minimum and maximum were calculated. For all continuous variables, the normality tests, the Kolmogorov-Smirnov test, were performed. No continuous variable was normal, as all $p$-values were below 0.05 . Below are the $p$-values indicating the non-normality of the data (Table 1).

The Mann-Whitney test (for two categories) and the Kruskal-Wallis test (for three or more categories) were used to compare the FRAQ-Brazil with categorical variables; the Kruskal Wallis test was used to compare the Morse Scale with continuous variables; the chi-square test was used to compare the Morse Fall Scale with categorical variables. The Kruskal-Wallis test was used to compare the pain scale with continuous variables; the chi-squared test was used to compare the pain scale with categorical variables.

Table 1 - Kolmogorov-Smirnov test for the variables age, family income, dependents, and Falls Risk Awareness Questionnaire. São Paulo (SP), Brazil, 2019-2020 ( $n=197)$

\begin{tabular}{lc}
\multicolumn{1}{c}{$\begin{array}{c}\text { Normality Test } \\
\text { (Kolmogorov-Smirnov) }\end{array}$} & p-value \\
Age & $<0.0001$ \\
Family income & $<0.0001$ \\
Dependents & $<0.0001$ \\
Falls Risk Awareness Questionnaire & 0.009 \\
\hline
\end{tabular}

Source: Research data, 2020.
The level of significance was set at 5\% ( $p$-value $<0.05$ ). The Statistical Package for Social Sciences (SPSS) version 19 was used for the analysis.

The study was approved by the Research Ethics Committee Involving Human Beings of the Federal University of São Paulo (protocol 1031/2019, opinion: 3.766.773, CAAE: 22113719.6.0000.5505). This project followed the recommendations of Good Clinical Practice and of Resolution No. 466 of 2012 of the National Health Council/Ministry of Health.

\section{RESULTS}

The mean age of the older adults was 72.57 (SD=6.45) years. The mean length of hospital stay was $5.89(S D=24.69)$ days. Most participants were male (122; 58.90\%), white (126; $61.50 \%)$, married $(114 ; 55.10 \%)$, retired $(155 ; 74.90 \%)$, with incomplete primary education $(80 ; 38.80 \%)$ and a family income between $\mathrm{R} \$ 628.00$ and $\mathrm{R} \$ 22,000.00$. Most had a caregiver $(133 ; 64.3 \%)$, reported morbidities $(191 ; 97.10 \%)$, with systemic arterial hypertension as the main one (159; $76.8 \%$ ) and had no support network (137; 66.8\%).

Table 2 shows the association between the FRAQ-Brazil and socio-demographic and clinical variables. Older adults with complete elementary education had a worse perception and knowledge of the risks of falling than patients with higher education. Those with a support network had lower perception and knowledge of the risk of falling when compared to those without a support network. Older adults with comorbidities and impaired walking had better perception and knowledge of the risks of falling than those with no comorbidities or impaired walking. Patients who used antihypertensive and lipid-lowering medication had a worse perception and knowledge than those who did not use these medications.

The association between the Morse Fall Scale and the socio-demographic, economic and clinical variables of the older adults showed that those with a high risk of falls were older, had a higher family income and a higher number of dependents. Patients with a caregiver and support network had a higher percentage of high risk of falls than those with no caregiver and no support network. Older adults with hypertension and impaired walking had a higher percentage of high risk of falls than those without hypertension or impaired walking. Patients who used medication, who were using antihypertensive and lipid-lowering medication had a higher percentage of high risk of falls when compared to those who were not (Table 3). 
Table 2 - Association between the Falls Risk Awareness Questionnaire and socio-demographic and clinical variables of older adults hospitalized in the Emergency Department. São Paulo (SP), Brazil, $2019-2020$ ( $n=197)$

\begin{tabular}{|c|c|c|c|}
\hline & \multicolumn{2}{|c|}{ Falls Risk Awareness Questionnaire } & \multirow{2}{*}{ p-value } \\
\hline & number & Median (minimum-maximum) & \\
\hline \multicolumn{4}{|l|}{ Level of Education* } \\
\hline Illiterate & 21.0 & $21.0(10-26)$ & 0.0109 \\
\hline Incomplete elementary education & 77.0 & $21.0(12-27)$ & \\
\hline Elementary education & 36.0 & $18.0(9-27)$ & \\
\hline High school & 44.0 & 20.0(13-28) & \\
\hline Higher education & 19.0 & $21.0(16-26)$ & \\
\hline \multicolumn{4}{|l|}{ Support network ${ }^{+}$} \\
\hline No & 63.0 & $21.0(9-28)$ & 0.0025 \\
\hline Yes & 134.0 & 19.0(10-28) & \\
\hline \multicolumn{4}{|l|}{ Comorbidities $^{\dagger}$} \\
\hline No & 6.0 & $18.5(10-20)$ & 0.0496 \\
\hline Yes & 191.0 & $20.0(9-28)$ & \\
\hline \multicolumn{4}{|l|}{ Impaired walking ${ }^{\dagger}$} \\
\hline No & 139.0 & $20.0(9-28)$ & 0.0009 \\
\hline Yes & 58.0 & $22.0(13-28)$ & \\
\hline \multicolumn{4}{|l|}{ Anti-hipertensive $^{\dagger}$} \\
\hline No & 51.0 & $21.0(10-28)$ & 0.0323 \\
\hline Yes & 146.0 & 20.0(9-28) & \\
\hline \multicolumn{4}{|l|}{ Lipid-lowering medication $^{\dagger}$} \\
\hline No & 126.0 & $21(10-28)$ & 0.0463 \\
\hline Yes & 71.0 & $20.0(9-27)$ & \\
\hline
\end{tabular}

Source: Research data, 2020.

* Kruskal-Wallis Test

† Mann-Whitney Test 
Table 3 - Association between the Morse Fall Scale and the socio-demographic, economic and clinical variables of older adults hospitalized in the Emergency Service. São Paulo (SP), Brazil, 2019-2020 ( $n=197)$

\begin{tabular}{|c|c|c|c|c|}
\hline & & Morse Scale & & \\
\hline & Low risk & Medium risk & High risk & \\
\hline $\mathrm{Age}^{*}$ & $69(65-79)^{\ddagger}$ & $71(65-93)^{\ddagger}$ & $73(65-88)^{\ddagger}$ & 0.0041 \\
\hline Family income* & $998(998-4200)^{\ddagger}$ & $1649(998-12000)^{\ddagger}$ & $1996(628-22000)^{\ddagger}$ & 0.0274 \\
\hline Dependents* & $1(0-4)^{\ddagger}$ & $2(0-6)^{\ddagger}$ & $2(0-12)^{\ddagger}$ & 0.0272 \\
\hline Caregiver $^{\dagger}$ & & & & \\
\hline Yes & $10(7.50 \%)^{\S}$ & $41(30.80 \%)^{\S}$ & $82(61.70 \%)^{\S}$ & $<0.0001$ \\
\hline No & $21(28.40 \%)^{\S}$ & $28(37.80 \%)^{5}$ & $25(33.80 \%)^{5}$ & \\
\hline Support networl & & & & \\
\hline Yes & $2(2.90 \%)^{\S}$ & $19(27.90 \%)^{\S}$ & $47(69.10 \%)^{\S}$ & 0.0002 \\
\hline No & $29(21.20 \%)^{\S}$ & $50(36.50 \%)^{\S}$ & $58(42.30 \%)^{\varsigma}$ & \\
\hline Sistemic arterial & & & & \\
\hline Yes & $19(11.90 \%)^{\S}$ & $48(30.20 \%)^{\S}$ & $92(57.90 \%)^{\S}$ & 0.0036 \\
\hline No & $12(25.00 \%)^{\S}$ & $21(43.80 \%)^{\S}$ & $15(31.30 \%)^{5}$ & \\
\hline Impaired walkin & & & & \\
\hline Yes & $2(3.40 \%)^{5}$ & $13(22.00 \%)^{5}$ & $44(74.60 \%)^{\S}$ & 0.0001 \\
\hline No & $29(19.60 \%)^{\S}$ & $56(37.80 \%)^{5}$ & $63(42.60 \%)^{5}$ & \\
\hline Uses medication & & & & \\
\hline Yes & $25(13.20 \%)^{5}$ & $61(32.30 \%)^{5}$ & $103(54.50 \%)^{\S}$ & 0.0144 \\
\hline No & $6(33.30 \%)^{\S}$ & $8(44.40 \%)^{5}$ & $4(22.20 \%)^{\S}$ & \\
\hline Antihipertensive & & & & \\
\hline Yes & $18(11.70 \%)^{\S}$ & $45(29.20 \%)^{5}$ & $91(59.10 \%)^{\S}$ & 0.0010 \\
\hline No & $13(24.50 \%)^{\S}$ & $24(45.30 \%)^{\S}$ & $16(30.20 \%)^{\S}$ & \\
\hline Lipid-lowering m & & & & \\
\hline Yes & $2(2.70 \%)^{\S}$ & $20(26.70 \%)^{\S}$ & $53(70.70 \%)^{\varsigma}$ & $<0.0001$ \\
\hline No & $29(22.00 \%)^{\S}$ & $49(37.10 \%)^{\S}$ & $54(40.90 \%)^{\S}$ & \\
\hline
\end{tabular}

Source: Research data, 2020.

tResults expressed as median (minimum-maximum)

SResults expressed as number (percentage)

* Kruskal Wallis test

${ }^{\dagger}$ chi-squared test 
The association between the pain scale and socio-demographic and economic variables showed that older adults with complete primary education had a higher percentage of no pain, while those with higher education had a higher percentage of moderate pain and a lower percentage of severe pain. Patients with a religion had a higher percentage of severe pain and a lower percentage of no pain. Respondents with a support network had a lower percentage of severe pain and a higher percentage of no pain. Patients with no pain had a higher number of dependents when compared to those with mild pain (Table 4).
In this study, there was no statistically significant relationship between the perception of the risk of falling and the risk of falling $(p=0.7088)$. There was also no statistically significant relationship between the risk of falling and pain in the participants surveyed $(p=0.1136$ ). However, most were at high risk of falls and, of these, $45.80 \%$ had moderate to severe pain. Older adults with severe pain had better perception and knowledge of the risk of falls when compared to those without pain ( $p=0.0020$ ).

Table 5 shows that the older adults had good perception and knowledge about falls. Most were at high risk for falls and had no pain.

Table 4 - Association between the pain scale and socio-demographic and economic variables of older adults hospitalized in the Emergency Service. São Paulo (SP), Brazil, 2019-2020 ( $n=197)$

\begin{tabular}{|c|c|c|c|c|c|}
\hline & \multicolumn{4}{|c|}{ Pain Scale } & \multirow{2}{*}{ p-value } \\
\hline & No pain & Mild pain & Moderate pain & Severe pain & \\
\hline \multicolumn{6}{|l|}{ Level of education* } \\
\hline Illiterate & $9(40.90 \%)^{\ddagger}$ & $5(22.70 \%)^{\ddagger}$ & $2(9.10 \%)^{\ddagger}$ & $6(27.30 \%)^{\ddagger}$ & 0.0032 \\
\hline $\begin{array}{l}\text { Incomplete } \\
\text { elementary education }\end{array}$ & $18(22.50 \%)^{\ddagger}$ & $14(17.50 \%)^{\ddagger}$ & $25(31.30 \%)^{\ddagger}$ & $23(28.80 \%)^{\ddagger}$ & \\
\hline Elementary education & $24(60.00 \%)^{\ddagger}$ & $6(15.00 \%)^{\ddagger}$ & $6(15.00 \%)^{\ddagger}$ & $4(10.00 \%)^{\ddagger}$ & \\
\hline High school & $19(42.20 \%)^{\ddagger}$ & $10(22.20 \%)^{\ddagger}$ & $10(22.20 \%)^{\ddagger}$ & $6(13.30 \%)^{\ddagger}$ & \\
\hline Higher education & $8(42.10 \%)^{\ddagger}$ & $1(5.30 \%)^{\ddagger}$ & $8(42.10 \%)^{\ddagger}$ & $2(10.50 \%)^{\ddagger}$ & \\
\hline \multicolumn{6}{|l|}{ Religion* } \\
\hline Yes & $68(35.80 \%)^{\ddagger}$ & $32(16.80 \%)^{\ddagger}$ & $49(25.80 \%)^{\ddagger}$ & $41(21.60 \%)^{\ddagger}$ & 0.0208 \\
\hline No & $10(58.80 \%)^{\ddagger}$ & $4(23.50 \%)^{\ddagger}$ & $3(17.60 \%)^{\ddagger}$ & $0(0.00 \%)^{\ddagger}$ & \\
\hline \multicolumn{6}{|l|}{ Support network* } \\
\hline Yes & $34(50.00 \%)^{\ddagger}$ & $15(22.10 \%)^{\ddagger}$ & $14(20.60 \%)^{\ddagger}$ & $5(7.40 \%)^{\ddagger}$ & 0.0033 \\
\hline No & $44(32.10 \%)^{\ddagger}$ & $21(15.30 \%)^{\ddagger}$ & $36(26.30 \%)^{\ddagger}$ & $36(26.30 \%)^{\ddagger}$ & \\
\hline Dependents $^{\dagger}$ & $2(0-12)^{\S}$ & $1(0-5)^{\S}$ & $2(0-6)^{\S}$ & $2(0-7)^{\S}$ & 0.0156 \\
\hline
\end{tabular}

Source: Research data, 2020

${ }^{\ddagger}$ Results expressed as number (percentage)

${ }^{\S}$ Results expressed as median (minimum-maximum)

${ }^{*}$ Chi-squared test

tKruskal-Wallis test 
Table 5 - Scores of the older adults on the Falls Risk Awareness Questionnaire (FRAQ-Brazil), Morse Fall Scale and pain scale. São Paulo (SP), Brazil, 2019-2020 $(n=197)$

\begin{tabular}{|c|c|}
\hline \multicolumn{2}{|l|}{ Escalas } \\
\hline $\begin{array}{l}\text { Falls Risk } \\
\text { Awareness Questionnaire }\end{array}$ & $20(9-28)^{\ddagger}$ \\
\hline Morse Fall Scale & \\
\hline Low risk & $31(15.00 \%)^{\S}$ \\
\hline Medium risk & $66(33.30 \%)^{\S}$ \\
\hline High risk & $100(51.70 \%)^{\S}$ \\
\hline \multicolumn{2}{|l|}{ Pain scale } \\
\hline No pain & $72(37.70 \%)^{\S}$ \\
\hline Mild pain & $33(17.40 \%)^{\S}$ \\
\hline Moderate pain & $51(25.10 \%)^{\S}$ \\
\hline Severe pain & $41(19.80 \%)^{\S}$ \\
\hline
\end{tabular}

Source: Research data, 2020

${ }^{\ddagger}$ Results expressed as median (minimum-maximum))

${ }^{\S}$ Results expressed as number (percentage)

\section{DISCUSSION}

Older adults with complete elementary education had worse perception and knowledge about the risks of falling than patients with higher education. This finding is in line with the literature, which reports that older adults with greater knowledge about falls choose to modify household risks; on the other hand, the low level of knowledge on the subject and the lack of perception that a fall can have an important outcome for the health of the older adult can be predictive factors for loss of autonomy and social and psychological damage in this age group ${ }^{(16)}$ In addition, studies indicate that the level of education influences the spatial perception of older adults, meaning that, when performing visual search tasks, individuals with a low level of education need more time, make more mistakes and reach fewer targets when compared to individuals with higher levels of education ${ }^{(17)}$

The participants who had a support network in place had lower perception and knowledge of the risk of falls and a higher percentage of high risk of falls when compared to those without a support network. The lower perception and knowledge of the risk of falls may be associated with the sense of security provided by their support network, which can lead them to neglect situations that put them at risk of falling ${ }^{(18)}$ This is concerning, as most of the older adults in this study were at high risk of falling.

Older adults with comorbidities, impaired walking and hypertension had better perception and knowledge about the risks of falls and a higher percentage of high risk of falls than those with no comorbidities or impaired walking. These findings may be related to the fact that the older adults in these health conditions do not perceive themselves as healthy and, therefore, consider themselves to be at risk of falling, which can lead them to adopt preventive behaviors. The occurrence of falls is associated with the presence of morbidities - including arterial hypertension ${ }^{(10)}$.

Patients who used antihypertensive and lipid-lowering medication had a worse perception and knowledge about falls and had a higher percentage of high risk of falls when compared to those who did not use these medications. This is concerning, as these medications have side effects such as nausea, fatigue, headache, diarrhea, orthostatic hypotension, flatulence, dyspepsia, among others, and the older adult may not adopt preventive measures for falls ${ }^{(19)}$

In line with the findings of this study, another research found that older adults at high risk of falls are older, have a higher family income, and a greater number of dependents. The risk of falling increases significantly with advancing age and frailty, and contributes to the loss of independence in one or more activities of daily living ${ }^{(20-21)}$

Unlike the results of this study, which showed an association between higher family income and number of dependents and risk of falls, another study pointed to an inverse association, that is, the lower the income, the greater the risk of falling ${ }^{(22)}$ Falls are a multifactorial phenomenon, meaning that, in addition to income and number of dependents, other factors that were not evaluated in this research may be associated with the risk of falls, such as depression, functional disability, loss of independence, and decline in quality of life.

Patients with a caregiver and support network have a higher percentage of high risk of falls and are more likely to have functional limitations that make them need caregivers. This finding also draws attention to the fact that health professionals, especially nurses, should act as educators and guide the caregiver about the risks related to falls. This can support the adoption of preventive measures and reduce the probability of falls among the older population ${ }^{(14)}$.

Respondents with complete elementary education have a higher percentage of no pain, and those with higher education have a higher percentage of moderate pain. 
Patients with a religion had a higher percentage of severe pain. Respondents with a support network, in turn, had a higher percentage of no pain. Patients with no pain had a greater number of dependents. The higher level of education may have favored pain assessment, as a study shows that knowledge about the rights of the Unified Health System users is associated with a higher level of education, and pain relief is one of the patient's rights. Among the ways to cope with pain, it has been demonstrated that religiosity and spirituality are very important for controlling the stress in painful situations ${ }^{(10)}$ However, in this study, religiosity and spirituality were not associated with lower pain intensity.

In this research, there was no statistically significant relationship between the perception and knowledge of the risk of falling and the actual risk of falling. This can be explained by the fact that the perception and knowledge of the risk of falling are assessed by a scale in which the older adults assess themselves. The risk of falls, on the other hand, is an assessment of the older adult performed by the health professional, that is, the person may have a good perception and knowledge of the risk of falls and be classified as being at a high risk of falling by the health professional.

However, a better perception and knowledge of the risk of falling increases the probability of the older adult adopting preventive measures that reduce this risk. Older adults can prevent falls through several actions, such as improved lighting, removal of carpets from the household, proper use of shoes, among others measures that can be adopted. However, they may not be effective if the perception of the risk factors in their daily activities is not adequate ${ }^{(23)}$

There was no statistically significant relationship between the risk of falling and pain among the respondents. However, it is known that pain can trigger antalgic postures and claudications that alter the posture, balance, and gait, becoming a risk factor for falls ${ }^{(10)}$ In this study, older adults with severe pain showed better perception and knowledge about the risk of falls when compared to those without pain. The presence of pain can favor the perception of environmental hazards and their own functional capacities, contributing to the adoption of preventive measures by the older adult ${ }^{(19)}$

A study carried out with older adults of the community of Juiz de Fora (MG) found a mean of 19.5 points in the FRAQ-Brazil, a result similar to that found in this study, indicating that older adults in the community had good perception and knowledge about falls. The level of perception and knowledge about falls, when associated with changes in habits, changes in the household environment and increased adherence to the treatment for comorbidities, can be an important factor in the prevention of the risk of falls among older adults ${ }^{(24)}$
Corroborating the results of this research, a study carried out with older adults admitted to a university hospital in Pará identified a high risk of falls among the patients surveyed. The risk of falls is one of the indicators for assessing hospital quality with regard to patient safety, and its evaluation can help nurses plan actions to minimize the risk of falls ${ }^{(25)}$

There was a prevalence of absence of pain among the older adults interviewed in this study. However, the literature indicates that pain is one of the most expressive symptoms among older adults, affecting approximately $80 \%$ of these individuals. In addition, the presence of this symptom increases the occurrence of falls among older adults(26)

The findings related to the socio-demographic and economic characteristics of the interviewees of this study were similar to those of another study, carried out with older adults hospitalized in a university hospital in the state of Paraíba, which found a predominance of men, married, retired, with low educational level, low income, and length of hospital stay of 5.89 days ${ }^{(25)}$

The most prevalent comorbidity among those surveyed was systemic arterial hypertension. The literature has indicated that older adults with systemic arterial hypertension are at approximately seven times greater risk of having falls than those who do not have this morbidity ${ }^{(27)}$ This agrees with the results of this study, as most older adults were at high risk of falling (51.7\%).

\section{a CONCLUSION}

In this study, factors associated with risk, perception and knowledge of falls and pain among older adults were age, family income, number of dependents, caregiver, support network, hypertension, impaired walking, antihypertensive medication, lipid-lowering medication, level of education, comorbidities and religion.

The factors associated with the high risk of falls were older age, higher family income, higher number of dependents, having a caregiver, having a support network, hypertension, impaired walking, and use of antihypertensive and lipid-lowering drugs. A lower perception and knowledge about the risks of falls was associated with education, support network and antihypertensive and lipid-lowering medication. Presence of comorbidities and impaired walking were associated with a better perception and knowledge about the risks of falling. And moderate and severe pain were associated with higher education, having a religion and not having a support network.

Falls of older hospitalized patients lead to physical and psychological trauma, loss of independence and even death. The results found can help the interprofessional team to plan 
actions that increase the safety of hospitalized older patients, with a focus on mitigating factors associated with a high risk of falls, greater pain intensity, and worse perception and knowledge about the risks of falling. It is important to use not only the instrument that assesses the risk of falls and pain, but also the perception of the older adult regarding the risk of falls. With this data, the assistance plan for the prevention of falls can be more effective in achieving its goals.

As a limitation of the study, it is worth noting that the results can not be generalized to all hospital Emergency Services, as only one service was investigated. However, the data provided can support preventive measures for falls, as they are one of the main safety incidents. This knowledge is essential not only for the care field, but also for teaching and management.

\section{REFERENCES}

1. Jesus-Moraleida FR, Ferreira PH, Ferreira ML, Silva JP, Assis MG, Pereira LSM. The Brazilian Back Complaints in the Elders (Brazilian BACE) study: characteristics of Brazilian older adults with a new episode of low back pain. Braz J Phys Ther. 2018;22 (1):55-63. doi: https://doi.org/10.1016/j.bjpt.2017.06.018

2. World Health Organization (WHO). Are you ready? What you need to know about ageing [Internet]. Geneve:WH0; 2012 [cited 2020 Sep 24]. Available from: http:// www.who.int/world-health-day/2012/toolkit/background/en/

3. Cattelani L, Palumbo P, Palmerini L, Bandinelli S, Becker C, Chesani F, et al. FRAT-up, a web-based fall-risk assessment tool for elderly people living in the community. J Med Internet Res. 2015;17(2):e41. doi: https://doi.org/10.2196/jmir.4064

4. The prevention offalls in later life. A report of the Kellogg International Work Group on the Prevention of Falls by the Elderly. Dan Med Bull. 1987;34(4 Suppl.):1-24.

5. Burkett E, Martin-Khan MG, Scott J, Samanta M, Gray LC. Trends and predicted trends in presentations of older people to Australian emergency departments: effects of demand growth, population aging and climate change. Aust Health Rev. 2017;41(3):246-53. doi: http://doi.org/10.1071/AH15165

6. Stathakis V, Gray S, Berecki-Gisolf J. Fall-related injury profile for Victorians aged 65 years and older. Hazard. 2015 [cited 2020 Sep 24];80:1-24. Available from: https://www.monash.edu/__data/assets/pdf_file/0003/455961/MonashUni-Hazard-Issue-80-summer.pdf

7. Silvia MK, Costa DCM, Reis AMM. Risk factors associated with in-hospital falls reported to the patient safety commitee of a teaching hospital. Einstein (Sao Paulo). 2019;17(1):1-7. doi: https://doi.org/10.31744/einstein_journal/2019A04432

8. Cameron ID, Dyer SM, Panagoda CE, Murray GR, Hill KD, Cumming RG, et al. Interventions for preventing falls in older people in care facilities and hospitals. Cochrane Database Syst Rev. 2018 [cited 2020 Sep 24];9:CD005465. Available from: https://www.cochranelibrary.com/cdsr/doi/10.1002/14651858.CD005465. pub4/epdf/full

9. Blaz BSV, Azevedo RCS, Agulhó DLZ, Reiners AA0, Segri NJ, Pinheiro TAB. Percepção de idosos relacionada ao risco de quedas e seus fatores associados. Esc Anna Nery. 2020;24(1):e20190079. doi: https://doi.org/10.1590/2177-9465-EAN-2019-0079

10. Gautério DP, Zortea B, Santos SSC, Tarouco BS, Lopes MJ, Fonseca CJ. Risk factors for new accidental falls in elderly patients at traumatology ambulatory center. Invest Educ Enferm. 2015 [cited 2020 Sep 24];33(1):35-43. Available from: http:// www.scielo.org.co/pdf/iee/v33n1/v33n1a05.pdf
11. Abreu HCA, Reiners AAO, Azevedo RCS, Silva AMC, Abreu DROM, Oliveira AD. Incidence and predicting factors of falls of older inpatients. Rev Saúde Pública. 2015;49:37. doi: https://doi.org/10.1590/S0034-8910.2015049005549

12. Chehuen Neto JA, Braga NAC, Brum IV, Gomes GF, Tavares PL, Silva RTC, et al. Awareness about falls and elderly people's exposure to household risk factors. Ciênc Saúde Colet. 2018;23(4):1097-104. doi: https://doi. org/10.1590/1413-81232018234.09252016

13. Córdova MIP, Mier N, Curi EJM, Gómez TG, Quirarte NHG, Barrios FF. Personal and social determinants of health services utilization by Mexican older people. Int J Older People Nurs. 2015;5(3):193-201. doi: https://doi. org/10.1111/j.1748-3743.2009.00193.x

14. Smith AA, Silva A0, Rodrigues RAP, Moreira MAS, Nogueira JA, Tura LFR. Assessment of risk of falls in elderly living at home. Rev Latino-Am Enfermagem. 2017;25:e2754. doi: https://doi.org/10.1590/1518-8345.0671.2754

15. Machado ALC, Nascimento MMG, Magalhães AS, Pinheiro FC, Kakehasi A, Moraes EN, et al. Uso de medicamentos que aumentam o risco de queda entre pacientes com osteoporose na pós-menopausa. Rev Med Minas Gerais. 2018;28(Supl 5):eS280518. doi: http://www.doi.org/10.5935/2238-3182.20180130

16. Nogueira SL, Ribeiro RCL, Rosado LEFPL, Franceschini SCC, Ribeiro AQ, Pereira ET. Determinant factors of functional status among the oldest old. Rev Bras Fisioter. 2010;14(4):322-9. doi: https://doi.org/10.1590/S1413-35552010005000019

17. Cardoso TP, Oliveira PR, Volpato RJ, Nascimento VF, Rocha EM, Lemes AG. Experience and perception of family members on child's hospitalization in pediatric unit. Rev Enferm UFSM. 2019;9(e4):e:1-22. doi: http://doi.org/10.5902/2179769231304

18. Lampert CDT, Scortegagna SA. Avaliação das condições de saúde e distorções cognitivas de idosos com depressão. Aval Psicol. 2017;16(1):48-58. doi: http:// doi.org/10.15689/ap.2017.1601.06

19. Miranda DP, Santos TD, Santo FHE, Chibante CLP, Barreto EA. Quedas em idosos em ambiente domiciliar: uma revisão integrativa. REAID. 2017 [cited 2020 Sep 24]. Available from: http://www.revistaenfermagematual.com.br/index.php/ revista/article/view/560

20. Chehuen Neto JA, Brum IV, Braga NAC, Gomes GF, Tavares PL, Silva RTC, et al. Fall awareness as a determining factor of this event among elderly community residents. Geriatr Gerontol Aging. 2017;11(1):25-31. doi: http://doi.org/10.5327/ 22447-211520171600074

21. Falcão RMM, Costa KNFM, Fernandes MGM, Pontes MLF, Vasconcelos JMB, Oliveira JS. Risk of falls in hospitalized elderly people. Rev Gaúcha Enferm. 2019;40(esp):e20180266. doi: https://doi. org/10.1590/1983-1447.2019.20180266

22. Moura LA, Araújo JN, Fernandes AN, Carvalho RE, Silva HP, SantosVE, Ferreira Júnior $M A$, Vitor AF, et al. Fatores de risco para cair em idosos no ambiente hospitalar. Rev Cubana Enferm. 2017 [cited 2020 Sep 24];33(3) Available from: http://www. revenfermeria.sld.cu/index.php/enf/article/view/1049/282 .

23. Urbanetto JS, Creutzberg M, Franz F, Ojeda BS, Gustavo AS, Bittencourt HR, et al. Morse Fall Scale: translation and transcultural adaptation for the portuguese language. Rev Esc Enferm USP. 2013;47(3):568-74. doi: https://doi.org/10.1590/ S0080-623420130000300007

24. Vieira LS, Gomes AP, Bierhals 10, Farías-Antúnez S, Ribeiro CG, Miranda VIA, et al. Quedas em idosos no Sul do Brasil: prevalência e determinantes. Rev Saude Publica. 2018;52:22. doi:https://doi.org/10.11606/S1518-8787.2018052000103

25. Moura SBR, Vieira JPPN, Santos AMR, Mesquita GV, Ribeiro JLV. Percepção de idosos sobre o risco de queda. R Interd. 2017 [cited 2020 Sep 24];10(4):1-13. Available from: https://revistainterdisciplinar.uninovafapi.edu.br/index.php/ revinter/article/view/1291/pdf_214 
26. Mamani ARN, Reiners AA0, Azevedo RCS, Dalla Vechia ADR, Segri NJ, Cardoso JDC. Elderly caregiver: knowledge, attitudes and practices about falls and its prevention. Rev Bras Enferm. 2019;722(2 Suppl.):119-26. doi: https://doi. org/10.1590/0034-7167-2018-0276

\section{- Acknowledgments:}

We thank the São Paulo Hospital, São Paulo - SP, Brazil.

\section{- Authorship contributions:}

Conceptualization, Formal analysis, Research, Methodology, Software, Writing - original draft, Writing - proofreading and editing - Lidia Ferreira de Souza, Ruth Ester Assayag Batista, Cássia Regina Vancini Camapanharo, Paula Cristina Pereira da Costa, Maria Carolina Barbosa Teixeira Lopes, Meiry Fernanda Pinto Okuno.

Data curation - Lidia Ferreira de Souza.

The authors declare that there is no conflict of interest.

\section{- Corresponding author:}

Name: Lidia Ferreira de Souza

E-mail: lidiafs4@hotmail.com
27. Moraes SA, Soares WJS, Lustosa LP, BiltonTL, Ferrioli E, Perracini MR. Characteristics of falls in elderly persons residing in the community: a population-based study. Rev Bras Geriatr Gerontol. 2017;20(5):691-701. doi: https://doi. org/10.1590/1981-22562017020.170080

\section{Associate editor:}

